\title{
Sthiramati and Sílabhadra*
}

\section{Noriaki Hakamaya}

This paper reports an identity of the two passages on the dharma-kaya or dharmadhatu-viśuddhi_ one from Sthiramati's Sütrālamkāravrttibhāṣya (SAVBh) and the other from Sillabhadra's Budhabhümivyäkhāna (BBhV)—, and points out some possibilities and problems drawn from the identity ${ }^{1}$.

Sthiramati quotes a passge under the title *Buddhabhümisamädhițikā (Sans rgyas kyi sahi tin ne hdsin ti ka), which he regards as the authority of his interpretation on the MSA IX-602). The passage is as follows:

3) thog ma gñis pahi gnas yin shes bya ba la thog ni chos kyi sku la bya stel chos kyi sku ni rdsogs lons spyod pahi sku dan sprul sku gñis kyi gnas nas rten yin no shes bya bahi don toll

de bas na Sañs rgyas kyi sahi tiñ ṅe hldsin ti ka las kyan "de la chos kyi rnam grans mthah dag thos pahi bag chags yons su smin pas ma lus par bsgoms pa rgyu[r] gyur pahi rtag tu sems can thams cad la phan pa dan bde ba skye bahi phyir

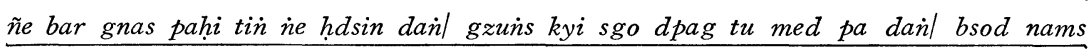
dañ ye ses kyi tshogs dan ldan pa śes bya dañ non mons pahi sgrib pa thams cad las dben pa ni chos kyi dbyins rnam par dag pa stel chos thams cad kyi de bshin ñid doll phyin ci ma log pahi ran bshin yin noll hphags pahi chos thams cad kyi skye bahi rgyuholl de bshin gśegs pa thams cad kyi bdag ñid do" shes bśad doll

The same passage as underlined is found in the $B B h V$ of Sillabhadra which runs as follows:

* This paper is substantially the same as the 2nd section of my article: "Shōjōhokkai kō (A Consideration on the Dharmadhătuviśuddhi, in Japanese)" contributed to the Nanto bukkyō, No. 37 (unpublished).

1) It is a pleasure to express my gratitude to Prof. D. Seyfort Ruegg, who made many helpful suggestions when I had asked about the identity of the two passages in the SAVBh and the BBhV (March 18th, 1972).

2) S. Lévi, ed., Mahāyāna-Sütrālamkāra, p. 45, l. 4, "prathamas tu dvayâśrayah."

3) P. ed., No. 5530, Bi, $152 b^{2-6}$. 
4) ji skad du sinar bśad pa bshin de la chos kyi rnam grains mthah dag thos pahi bag chags yons su smin pas ma lus par bsgoms pa rgyur gyu pal rtag tu sems can thams cad la phan pa dan bde ba ñe bar bskyed par bya bahi phyir ñe bar gnas pa

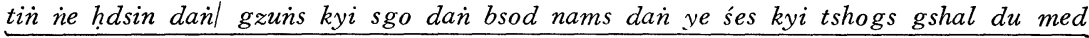

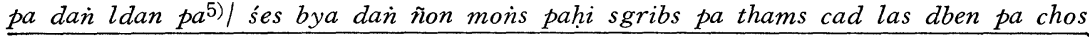
kyi dbyins rnam par dag pa ni chos thams cad kyi de bshin ñid phyin ci ma log pahi rain bshin hphags pahi chos thams cad ñe bar bskyed pahi rgyu stel de bshin gśegs pa thams cad kyi bdag nid yin noll

There can be no doubt about the identity of the two passages underlined ${ }^{6}$, from which we will be able to suppose the two possibilities.

Possibility 1: Both Sthiramati and Sillabhadra have quoted from the same. source, namely the *Buddhabhumisamadhițik $\bar{a}^{7)}$, which the former indicates by the actual name but the latter suggests with the words " $j i$ skad du snar dsad" pa bshin."

Possibility 2: The title *Buddhabhümisamädhițika was in general use as an alternative to the $B B h V$ of Sillabhadra. Sthiramati had quoted it under the former title. In this case, the passage has to be by Sílabhadra originally. Therefore, the words " $j i$ skad $d u$ sñar díad pa bshin (as mentioned above)" do.

4) P. ed., No. 5498, Chi, 300a $\mathrm{a}^{1-4}$. Kyoo Nishio, ed., The Buddhahbümi-Sütra and the Buddhabhümi-Vyākhyāna of Sílabhadra, (Nagoya, 1940), p. 60, ll. 1-13. In this. paper, reference to this text is according to the former, for the latter seems not to be available for Western scholars.

5) Accoeding to K. Nishio, the passage is divided here into two parts. See, Nishio, ibid. and his Bucchikyōron no kenkyü (A Study on the Buddhabhümivyākhyāna, in Japanese), pp. 210-211. However, this division is unfit in comparison with the quotation in the $S A V B h$.

6) Some differences between the two are attributed to their translation. Ex. "skye bahi phyir (SAVBh)", "ñe bar bskyed par bya bahi phyir (BBhV)" = upapattyartham. "dpag tu med pa (SAVBh)", "gshal du med pa (BBhV)"= aprameya. "kyi skye bahi rgyu (SAVBh)", "ñe bar bskyed pahi rgyu (BBhV)"=upapattihetu, etc.

7) The Fo-ti-ching-lun (佛地經論, Taishō ed., No. 1530) is said to have been written by *Bandhuprabha, etc. (親光菩薩等造). Therefore, there seems to have been another commentaries on the Buddhabhumisütra, one of which is called the *Buddhabhümisamädhițīă. 
not introduce a quotation, but indicate his own passage mentioned above.

Between these possibilities, it seems to us that the former is more suitable for the already-known facts though we are not able to have any information: about the *Buddhabhūmisamãdhițīka . The latter, however, presents a difficulty' about the relationship between Sthiramati and Sillabhardra. According to Prof.. E. Frauwallner, the lifetime of Sthiramati is fixed as 510-570 A. D. and hisfield of activity was in Valabhīi) while Silabhadra was 30 years old in the558 A. D. when his teacher Dharmapāla had retired under the Bodhi-tree ${ }^{9)}$,. that is to say, he was born in 529 A. D. Thus Sthiramati in 19 years older than Śllabhadra. Therefore it is not impossible but difficult that the former quotes the latter as the authority of his interpretation. The difficulty seems to" reject the possibility 2 . But the possibility should not be neglected flatly, beca-use the words "ji skad du snar bśad pa bshin" may prove that the pas-sage below them is written by Sillabhadra himself if they indicate his own. passage mentioned above10). The words "sinar ji skad du bśad pa bshin" or. " ji skad du snar bśad pa(hi) bshin"11) in another places of the BBhV" would rather indicate the foregoing passage than introduce a quotation.

In this paper, we cannot draw a decisive conclusion only from the identity of two passages in the $S A V B h$ and the $B B h V$, but we have pointed out. the two possibilities. If the possibility 2 is strengthened by some way, it would be open to re-examine into the relationship between Sthiramati and Sílabhadra..

(July 30th, 1976)

8) E. Frauwallner, "Landmarks in the History of Indian Logic," WZKO, V (1961),. pp. 136-137. H. Ui puts Sthiramati in 470-550 A. D. But his view on the date of Sthiramati has not accepted today by most Japanese scholars.

9) E. Frauwallner, ibid., p. 133. H. Ui puts Śilabhadra in 529-645 A. D. It agrees. with Frauwallner's. But, according to the former, it was in 634 A. D. that Hiuan-tsang met his teacher Śilabhadra in Nālandā.

10) It seems to me that the words indicate the foregoing passage, namely Chi, 299a300a, especially, "chos kyi dbyins la dmigs pas thos pa ma lus par hdsin pa dain|

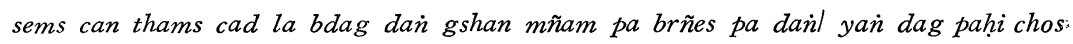
rab tu ston pahi thabs dain gshan la phan h̆dogs pahi rgyu niho/l (299a $\mathrm{a}^{7-8}$ )".

11) See, Chi, 287a $\mathrm{a}^{4}$ and $298 \mathrm{a}^{1}$. Concerning the latter, Nishio (op. cit., p. 208, n. 1) notes that the words indicate the foregoing passage, Chi, $294 \mathrm{~b}^{2-6}$. 